\title{
Protein Comparisons of Non- and Cold-acclimated Hibiscus syriacus and H. rosa-sinensis Bark
}

\author{
Rita L. Hummel ${ }^{1}$, Thomas M. Teets, and C.L. Guy \\ Ornamental Horticulture Department, Institute of Food and Agricultural \\ Sciences, University of Florida, Gainesville, FL 32611
}

Additional index words. Chinese hibiscus, Rose-of-Sharon, cold hardiness

Short photoperiod and low temperature (5C) were used to induce cold acclimation of $\mathrm{Hi}$ biscus syriacus L., a deciduous, temperate woody species, and $H$. rosa-sinensb L., an evergreen, tropical woody species (Bailey Hortorium, 1976; Watkins and Sheehan, 1975). Protein extracts from acclimated and nonacclimated plants of the two species were compared by electrophoresis in an effort to detect changes in the protein content in response to low-temperature exposure.

One-year-old plants of a single, white (SW) flowered $H$. syriacus and $H$. rosa-sinensis 'President' were grown in 3.8-liter containers in a shadehoyse (47\% light exclusion) under the natural temperature and photoperiod conditions of Gainesville, Fla. On 11 June, 10 uniform plants of both species were randomly placed in a controlled environment chamber. Chamber temperature was maintained at $5 \pm 2 \mathrm{C}, 70 \% \pm 5 \% \mathrm{RH}$ with a 12-hr photoperiod consisting of 520 $\mu \mathrm{mol} \cdot \mathrm{s}^{-1} \cdot \mathrm{m}^{-2}$ PPFD. Control plants were kept in the shadehouse under ambient environmental conditions with a day/night range of 32 to $24 \mathrm{C}$. All plants were watered and fertilized as needed. Stem samples were taken 5 weeks after the initiation of low-temperature treatment from acclimated and control plants and tested for freezing tolerance (Teets and Hummel, 1988; Teets et al., 1989). A 5-week photoperiod/temperature treatment was sufficient to promote changes in freezing tolerance of $H$. syriacus (Teets et al., 1989). Concomitantly, bark extracts of protein were prepared for gel electrophoresis.

Total protein was extracted (Schuster and Davies, 1983; Van Etten et al., 1979). Bark tissue $(100 \mathrm{mg})$ was homogenized in $300 \mu 1$ of extraction buffer $(120 \mathrm{mM}$ TrisHCl, $\mathrm{pH}$ $6.8 ; 50 \mathrm{~mm}$ ethylenediaminetetracetic acid; $100 \mathrm{mM} \mathrm{KCl} ; 1 \mathrm{mM}$ phenylmethylsufonylfluoride; $2 \%$ sodium dodecyl sulfate; $2 \% 2$ mercaptoethanol) at $0 \mathrm{C}$. An equal volume of $80 \%$ buffer-saturated phenol was mixed with the tissue extract and vortexed at maximum

Received for publication 30 Jan. 1989. Univ. of Florida Journal Series no. 8452. This research was funded in part by a grant from the American Hibiscus Society Charitable Trust. The cost of publishing this paper was defrayed in part by the payment of page charges. Under postal regulations, this paper therefore must be hereby marked advetisement solely to indicate this fact.

${ }^{1}$ Present address: Washington State Univ., Puyallup, 7612 Pioneer Way, Puyallup, WA 98371. speed for $2 \mathrm{~min}$. Phase separation was achieved by centrifugation for $5 \mathrm{~min}$ at $15,000 \times g$ at $4 \mathrm{C}$. The phenol phase containing the protein was washed three times with equal volumes of extraction buffer. Protein was precipitated by the addition of five volumes of $-20 \mathrm{C}$ methanol containing $100 \mathrm{~mm}$ ammonium acetate and stored overnight at -20C. After centrifugation, the protein pellet was washed three times with - 20C methanol containing ammonium acetate and once with $-20 \mathrm{C}$ acetone and air dried. Protein was dissolved in sample buffer (120 mM Tris $\cdot \mathrm{HCl}, \mathrm{pH} 6.8 ; 10 \%$ glycerol; $1 \%$ sodium dodecyl sulfate; and $1 \%$ dithiolthreitol). Proteins (50 $\mu \mathrm{g} /$ lane) were separated according to methods described by Laemmli (1970) in 12\% acrylamide gels and stained with Coomassie brilliant blue.

Hibiscus rosa-sinemis control plants and plants held 5 weeks at $5 \mathrm{C}$ failed to coldacclimate and were killed by freezing at - 2C. Hibiscus syriacus SW nonacclimated control plants had a $\mathrm{T}_{\mathrm{k} 50}$ (temperature killing 50\% of the samples) of $-4 \mathrm{C}$, while the plants held 5 weeks at $5 \mathrm{C}$ with a $12-\mathrm{hr}$ photoperiod had cold-acclimated and were not injured by freezing at -16C. Separation of total protein by one-dimensional denaturing gel electrophoresis failed to resolve major differences between species or between nonacclimated and cold-acclimated hibiscus bark tissue (Fig. 1). Exposure of $H$. syriacus to temperatures that induce cold-acclimation did not cause the appearance or loss of proteins in the bark tissue. Only recently, with the use of twodimensional gel analysis, have protein changes in response to cold acclimation been detected (Guy and Haskell, 1987). The lack of difference between the nonacclimated and coldacclimated $H$. syriacus protein content does not rule out subtle low temperature-induced changes that might have been revealed by a more powerful gel electrophoresis technique than the one-dimensional system used in this study. The protein content of $H$. rosa-sinensis held at $5 \mathrm{C}$ for 5 weeks was much reduced, and this was evident by the absence of most of the protein bands present in the control tissue. The loss of protein provides evidence that extended low-temperature exposure was deleterious to $H$. rosa-sinensis (Teets et al., 1989).

Although obvious changes in bark proteins associated with freezing tolerance were not observed, two notable differences were found. Bark tissue of $H$. rosa-sinensis con- tained a protein of $M_{r} 58,000$ that was not observed in $H$. syriacas. In contrast, $H$. syriacus contained a major band at $M_{r}$ 16,000 that was not apparent in $H$. rosa-sinensis. Otherwise, the profiles were identical in all respects and suggest a high degree of relatedness between the two species. The observation of only two protein band differences between the two species may be valuable to hibiscus breeders.

\section{Literature Cited}

Bailey Hortorium. 1976. Hortus third: A concise dictionary of plants cultivated in the United States and Canada. Macmillan, New York.

Guy, C.L., and D. Haskell. 1987. Induction of freezing tolerance in spinach is associated with the synthesis of cold acclimation induced proteins. Plant Physiol. 84:872-878.

Laemmli, U.K. 1970. Cleavage of structural proteins during the assembly of the head of bacteriophage T4. Nature (London) 227:680-685.

Schuster, A.M., and E. Davies. 1983. Ribonucleic acid and protein metabolism in pea epicotyls. Plant Physiol. 73:809-816.

Teets, T.M., and R.L. Hummel. 1988. Hibiscus freezing tolerance. HortScience 23(5):915.

Teets, T.M., R.L. Hummel, and C.L. Guy. 1989. Cold acclimation of Hibiscus rosa-sinensis L. and Hibiscus syriacus L. in natural and controlled environments. Plant Cell Environ. 12:495-502.

Van Etten, J.L., S.N. Freer, and B.K. McCune. 1979. Presence of a major (storage) protein in dormant spores of the fungus Botryodiplodia theobromae. J. Bacterial. 138:650-652.

Watkins, J.V. and T.J. Sheehan. 1975. Florida landscape plants. Univ. of Florida Press, Gainesville.

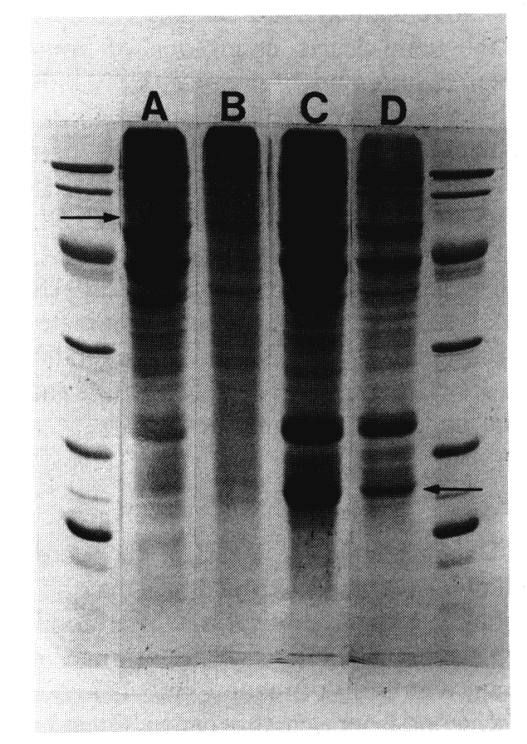

Fig. 1. Polypeptide profile of Hibiscus bark tissue separated in a $12 \%$ acrylamide gel and stained with Coomassie brilliant blue. H. rosa-sinensis nonacclimated (A) and cold-acclimated (B), $H$. syriacus nonacclimated (C) and cold-acclimated (D). Protein standards were phosphorylase $b$ 92,000; bovine serum albumin 66,000; ovalbumin 45,000; carbonic anhydrase 31,000; trypsin inhibitor 20,500; and cytochrome c 14,000 , Arrow adjacent to lane A denotes protein band present in $H$. rosa-sinensis, but missing in H. syriacus. Arrow adjacent to lane D denotes a protein band diminished by cold-acclimation treatment. 